\title{
STRATEGI BAURAN PEMASARAN DAN PENGARUHNYA TERHADAP KEPUTUSAN KONSUMEN
}

\author{
Musran Munizu (m3.feunhas@gmail.com) \\ Fakultas Ekonomi dan Bisnis Universitas Hasanudin, Makassar
}

\begin{abstract}
The purpose of this research is to investigate the effect of marketing mix strategy which consist of product, price, place, and promotion on customer decision of PT. Semen Bosowa in Makassar, and to analyze the dominant factor which influence customer decision of PT. Semen Bosowa in Makassar. Population in this research were the customers of cement product of Bosowa in Makassar. The amount of sample were 100 persons. The respondents were chosen by purposive random sampling from the population. Method of analyses which use in this research were both descriptive analysis and Multiple Regression Analysis. Processing data performed by SPSS 18.00. The result shows that marketing mix strategy which consists of product, price, place, and promotion have significant and positive effect on customer decision, and (2) Product factor has dominant effect on customer decision ( $\mathrm{t}$-value $=6,517$ ).
\end{abstract}

Keywords: product, price, place, promotion, and customer decision

\section{PENDAHULUAN}

Era keterbukaan dalam memasuki pasar global menjadi tantangan pengusaha dalam memacu dan memberikan pelayanan dalam menyalurkan hasil produknya sampai ketangan konsumen yang menjadi target sasaran pasar. Perubahan ekonomi yang terjadi akibat krisis moneter yang berkepanjangan memberikan dampak signifikan terhadap roda perekonomian bangsa sehingga mengalami perubahan radikal dalam dua dasawarsa terakhir ini. Kondisi persaingan yang semakin tajam mendorong perusahaan untuk menetapkan serangkaian strategi untuk memenangkan persaingan (Hitt et al., 2004).

Setiap organisasi perusahaan dalam menjalankan bisnisnya bertujuan untuk memperoleh laba (profit) agar tetap survive. Besarnya laba yang dicapai perusahaan akan mempengaruhi kualitas perusahaan dalam dunia bisnis. Untuk mendapatkan laba yang semaksimal mungkin atas kegiatan usahanya maka manajer senantiasa dituntut agar mampu mengelola perusahaan dengan baik sehingga mampu mendapatkan tingkat efisiensi yang maksimal dari penggunaan modalnya.

Suatu produk, baru dapat dikonsumsi setelah melalui proses kegiatan produksi dan pemasaran. Dengan demikian produksi membentuk terciptanya konsumen, sedangkan pemasaran membentuk terciptanya harga (price), karena itu kegiatan pemasaran berfungsi sebagai penghubung antara produksi dan konsumsi. Sebesar apapun produksi yang dihasilkan tanpa adanya kegiatan pemasaran maka produk tersebut tidak mempunyai nilai apa-apa. dan terciptanya nilai karena adanya kebutuhan melalui konsumsi (Craven, 2001; Hawkins et al., 2006).

Kebutuhan dan keinginan manusia semakin lama semakin bertambah besar, baik produk makanan, buku, bahkan perumahan. Hal tersebut merupakan suatu indikator bahwa tingkat pendapatan masyarakat semakin tinggi. Karena itu adalah sangat penting membedakan antara kebutuhan, keinginan dan permintaan. Kebutuhan (human needs) adalah 


\section{Musran Munizu}

ketidakberadaan beberapa kepuasan dasar. Manusia membutuhkan makanan, pakaian, tempat berlindung, keamanan, hak milik, dan harga diri. Kebutuhan tersebut tidak diciptakan oleh masyarakat maupun pasar, melainkan hakikat biologis yang dimiliki manusia (Purwadi, 2005).

Dasar pemikiran tumbuhnya kegiatan pemasaran dimulai dari timbulnya kebutuhan dan keinginan manusia yang beragam. Manusia membutuhkan makanan, udara, air, pakaian, dan tempat berlindung untuk bertahan hidup. Lebih dari itu manusia menginginkan kebutuhan lain seperti rekreasi, pendidikan, dan jasa-jasa lainnya. Manusia sebagai masyarakat konsumen memiliki berbagai referensi yang sangat kuat terhadap berbagai jenis merek tertentu dari berbagai produk dan jasa.

Menurut Kotler (2000) bahwa disamping kebutuhan, manusia juga dilengkapi keinginan (wants) yaitu hasrat akan pemuas kebutuhan yang spesifik. Meskipun kebutuhan manusia sedikit, tetapi keinginan mereka lebih banyak. Keinginan manusia terus dibentuk dan diperbaharui oleh berbagai kekuatan dan lembaga sosial seperti sekolah, keluarga, dan perusahaan. Sedangkan permintaan (demand) adalah keinginan akan suatu produk yang didukung oleh kemampuan dan kesediaan untuk membelinya. Suatu keinginan akan menjadi permintaan apabila didukung oleh daya beli.

Kotler dan Keller (2007) memberikan pengertian pemasaran sebagai suatu proses sosial dan manajerial yang didalamnya individu dan kelompok mendapatkan apa yang mereka butuhkan dan inginkan dengan menciptakan, menawarkan, dan mempertukarkan produk yang bernilai dengan pihak lain. Definisi di atas bersandar pada konsep, yaitu kebutuhan (needs), keinginan (wants), dan permintaan (demands), produk (barang, jasa dan gagasan), nilai, biaya dan kepuasan, pertukaran dan transaksi, hubungan dan jaringan pasar, serta pemasaran dan prospek.

Peter dan Olson (2000) mendefinisikan pemasaran adalah suatu proses perencanaan dan menjalankan konsep, harga, promosi, dan distribusi sejumlah ide, barang, dan jasa untuk menciptakan pertukaran yang mampu memuaskan tujuan individu dan organisasi. Boyd dan Walker (2005) mengemukakan bahwa pemasaran suatu proses sosial yang melibatkan kegiatan penting yang memungkinkan individu dan perusahaan mendapatkan apa yang mereka butuhkan dan inginkan melalui pertukaran dengan pihak lain untuk mengembangkan hubungan pertukaran. Kemudian Tjiptono (2003) mengartikan pemasaran sebagai proses sosial yang di dalamnya individu dan kelompok mendapatkan apa yang dibutuhkan dan inginkan dengan menciptakan, menawarkan dan mempertukarkan produk yang bernilai dengan pihak lain.

Kegiatan pemasaran yang baik harus didukung dengan strategi yang jitu. Hamel dan Prahalad dalam Supranto (2005) berpendapat bahwa strategi merupakan tindakan yang bersifat incremental (senantiasa meningkat) terus menerus dan dilakukan berdasarkan sudut pandang tentang apa yang diharapkan oleh para pelanggan dimasa depan. Dengan demikian perencanaan strategi hampir selalu dimulai dari :"apa yang dapat terjadi", bukan dimulai dari "apa yang terjadi". Terjadinya kecepatan inovasi pasar baru dan perubahan pola konsumen memerlukan kompetensi inti (core competencies). Perusahaan perlu mencari kompetensi di dalam bisnis yang dilakukan.

Kotler (2000) mengemukakan bahwa strategi bauran pemasaran berkaitan dengan kegiatan 4P (product, price, place, and promotion). Seseorang dapat memuaskan kebutuhan dan keinginan dengan produk. Menurut Keagen (2001) produk adalah segala sesuatu yang dapat ditawarkan pada pasar untuk memenuhi kebutuhan dan keinginan konsumen. Produk 


\section{Jurnal Manajemen Teori dan Terapan}

Tahun 5. No. 2. Agustus 2012

merupakan unsur utama dan paling penting dalam perusahaan. Suatu produk diartikan memiliki sifat-sifat fisik, ukuran, dan material.

Setiap perusahaan dalam menentukan harga maka pertama-tama perusahaan harus memutuskan apa yang ingin dicapai dengan penawaran produk tertentu perusahaan telah memilih pasar sasaran dan posisi pasarnya dengan cermat, maka strategi bauran pemasarannya termasuk harga akan cukup jelas. Semakin jelas tujuan perusahaan, semakin mudah untuk menetapkan harga, sehingga perusahaan dapat mengejar salah satu dari enam tujuan utama melalui harga yaitu: kelangsungan hidup perusahaan (survival), laba sekarang maksimum (maximum current profit), pendapatan sekarang maksimum (maximum current revenue), pertumbuhan penjualan maksimum (maximum sales growth), skimming pasar maksimum (maximum market skimming), atau kepemimpinan kualitas produk (product-quality leadership) (Kotler dan Keller, 2007).

Salah satu kegiatan perusahaan dalam mengusahakan agar produknya dapat diterima di pasaran adalah dengan melakukan promosi. Keberhasilan dari suatu promosi bukan semata-mata karena, promosinya itu sendiri tetapi interaksi dari komponen bauran pemasaran dengan pasar. Promosi merupakan suatu variabel dalam salah satu marketing mix yang sangat penting dilaksanakan oleh perusahaan dalam memasarkan produk dan jasa-jasanya, kadang-kadang istilah promosi dijadikan sebagai sinonim dengan istilah penjualan meskipun yang dimaksud itu promosi. Sebenarnya istilah penjualan itu hanya meliputi kegiatan pemindahan barang/jasa dan penggunaan penjualan jasa dan tidak terdapat kegiatan periklanan atau kegiatan yang ditujukan untuk mendorong permintaan.

Menurut Basuswastha (2002) promosi adalah arus informasi suatu arah yang dibuat untuk mengarahkan seseorang atau organisasi kepada tindakan yang menciptakan pertukaran dalam perusahaan. Secara garis besar, penulis dapat membagi beberapa komponen bauran promosi diantaranya adalah: (a) periklanan, (b) promosi penjualan, (c) penjualan perseorangan (personal selling), (d) publisitas, dan (e) saluran distribusi langsung.

Penggunaan perantara atau distributor oleh sebagian besar perusahaan karena keunggulan efisiensi dalam membuat barang-barang tersedia secara luas dan mudah diperoleh pasar sasaran. Melalui hubungan, pengalaman, spesialisasi, dan skala operasi mereka, sehingga perantara biasanya menawarkan pada perusahaan lebih banyak dari pada apa yang mereka peroleh sendiri. Tiap perantara yang melakukan tugas membawa produk dan kepemilikan lebih dekat ke pembeli akhir merupakan tingkat saluran. Karena produsen dan pelanggan akhir keduanya melakukan pekerjaan, dimana mereka merupakan bagian dari tiap saluran. Penggunaan saluran pemasaran tergantung pada produk yang dipasarkan, apakah produk konsumen atau produk industri (Kotler dan Keller, 2007).

Sehubungan dengan strategi bauran pemasaran, Hawkins et al. (2006) mengatakan bahwa strategi bauran pemasaran yang tepat dapat meningkatkan kinerja penjualan dan mempengaruhi keputusan konsumen. Perusahaan yang dapat memberikan kualitas pelayanan yang unggul dibandingkan pesaing, akan mempunyai basis pelanggan yang semakin banyak dan pada akhirnya akan lebih puas melalui pelayanan prima.

Penelitian yang menguji pengaruh atau hubungan antara bauran pemasaran dengan keputusan konsumen diantaranya dilakukan oleh Suryadi dan Hutomo (2005) mengungkapkan bahwa produk, harga, promosi, dan saluran distribusi secara simultan (bersama-sama) berpengaruh signifikan terhadap keputusan konsumen dalam pembelian Kartu prabayar IM3 di Kota Pontianak. Kemudian Sutrisno (2007) menemukan bahwa semua variabel bebas yakni 


\section{Musran Munizu}

produk, harga, promosi dan tempat berpengaruh terhadap pengambilan keputusan konsumen dalam pemilihan kredit pada koperasi serba usaha makmur sejati malang. Sejalan dengan penelitian di atas Parengkuan dan Sepang (2010) menemukan bahwa bauran pemasaran yang terdiri dari faktor produk, harga, promosi, tempat berpngaruh signifikan terhadap keputusan konsumen pada rental mobil CV. Central Manado.

Berdasarkan telaah teoritis dan empiris yang diuraikan, maka tujuan penelitian ini adalah untuk menganalisis pengaruh strategi bauran pemasaran yang terdiri atas faktor produk, harga, promosi, tempat terhadap keputusan konsumen dalam menggunakan produk semen dan untuk mengetahui faktor dominan yang mempengaruhi keputusan konsumen dalam menggunakan produk semen PT. Semen Bosowa di Kota Makassar.

\section{KERANGKA KONSEP DAN HIPOTESIS}

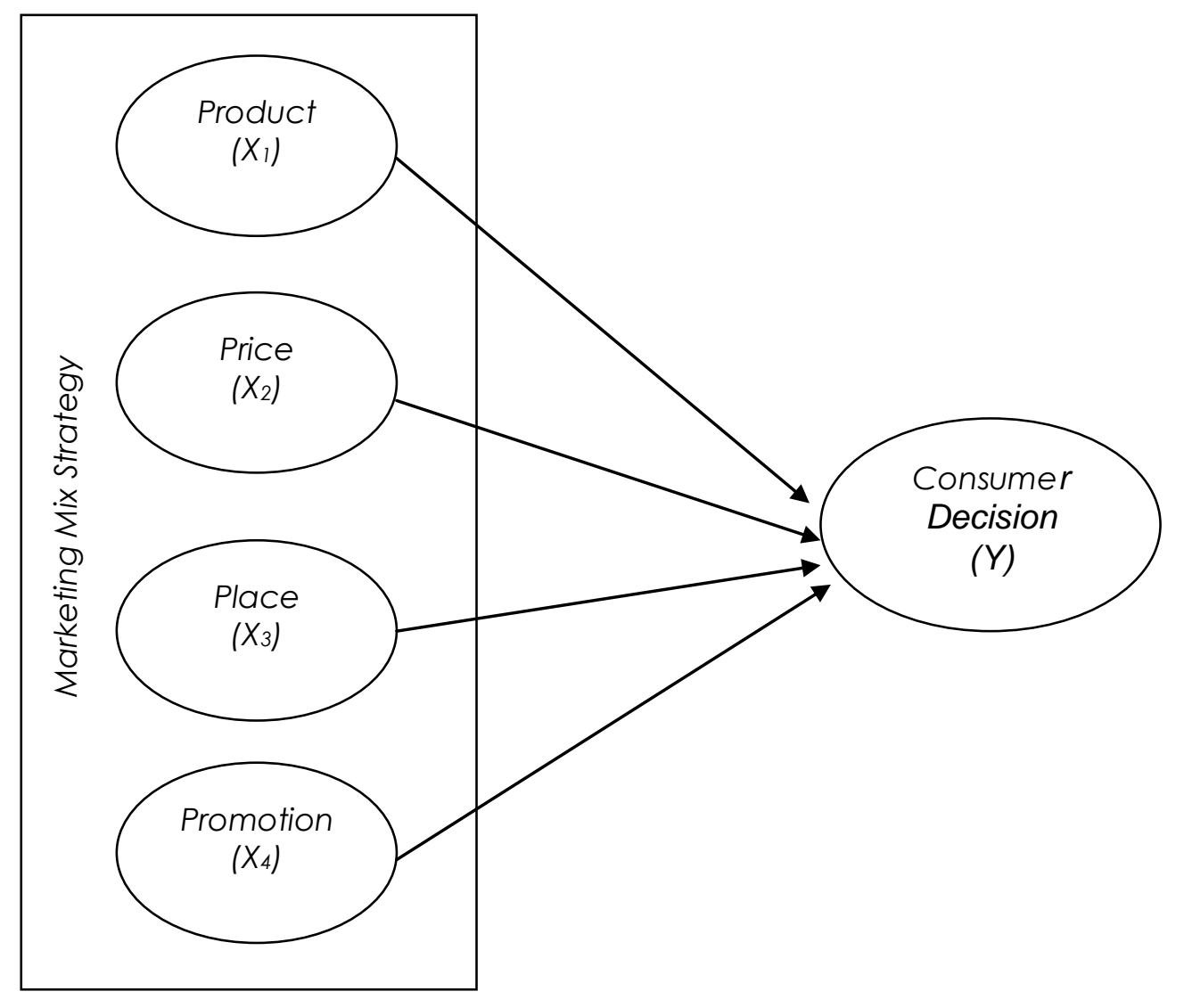

Gambar 1. Model Konseptual Penelitian

Berdasarkan telaah teoritis dan kerangka konsep yang disajikan di atas, maka dirumuskan hipotesis penelitian sebagai berikut:

1. Strategi product, berpengaruh siginifikan terhadap keputusan konsumen dalam menggunakan produk semen PT. Semen Bosowa di Kota Makassar.

2. Strategi price berpengaruh siginifikan terhadap keputusan konsumen dalam menggunakan produk semen PT. Semen Bosowa di Kota Makassar.

3. Strategi place berpengaruh siginifikan terhadap keputusan konsumen dalam menggunakan produk semen PT. Semen Bosowa di Kota Makassar. 
4. Strategi promotion berpengaruh siginifikan terhadap keputusan konsumen dalam menggunakan produk semen PT. Semen Bosowa di Kota Makassar.

5. Strategi produk mempunyai pengaruh dominan terhadap keputusan konsumen PT. Semen Bosowa di Kota Makassar.

\section{METODE PENELITIAN}

Unit analisis penelitian ini adalah pelanggan atau konsumen rumah tangga. Populasi dalam penelitian ini adalah seluruh konsumen atau pelanggan rumah tangga yang pernah menggunakan produk semen bosowa di Kota Makassar. Karena jumlah populasi yang relatif besar maka penentuan sampel dilakukan secara purposive. Adapun jumlah sampel ditetapkan sebesar 100 orang responden (Solimun, 2006; Sugiyono, 2008).

Pengumpulan data dilakukan dengan cara kuesioner, wawancara, dan dokumentasi. Untuk mengolah data hasil penelitian tersebut, maka digunakan metode analisis yang terdiri atas: (1) analisis deskriptif; dan (2) analisis regresi berganda (multiple regression analysis). Metode analisis regresi berganda digunakan untuk menguji pengaruh variabel bebas terhadap variabel tidak bebas, baik secara simultan atau bersama-sama maupun secara parsial (Solimun, 2006; Sugiyono, 2008). Adapun model regresi berganda dapat diformulasikan sebagai berikut:

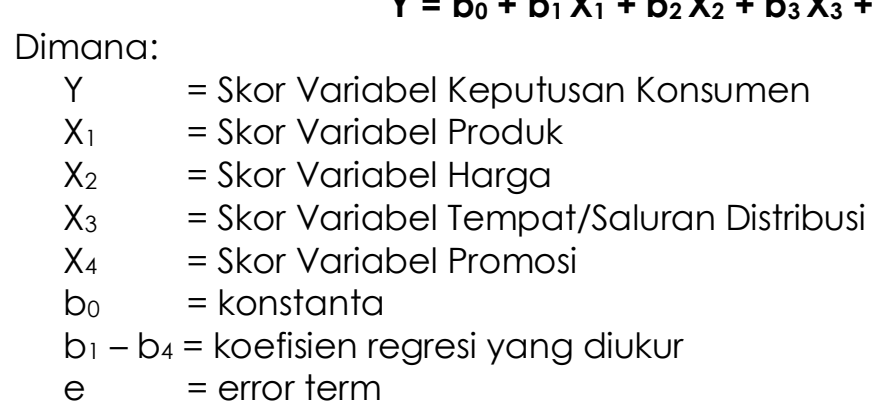

Uji Fisher (F-test) dignakan untuk menguji pengaruh variabel bebas terhadap variabel tidak bebas secara simultan, sedangkan Uji-† digunakan untuk menguji pengaruh masing-masing variabel bebas secara parsial terhadap variabel tidak bebas. Tingkat kepercayaan yang digunakan adalah $95 \%$ atau $a=5 \%$. Apabila nilai t-hitung > t-tabel, maka terdapat pengaruh signifikan antar variabel. Adapun jawaban responden diukur dengan menggunakan Skala Likert (Likert Scale) (Cooper and Emory, 1999; Sugiyono, 2008).

\section{HASIL DAN PEMBAHASAN}

Berdasarkan hasil analisis deskriptif, dapat disajikan gambaran umum karakteristik responden berdasarkan jenis kelamin seperti pada tabel berikut.

Tabel 1. Distribusi Responden Menurut Jenis Kelamin

\begin{tabular}{|c|l|c|c|}
\hline No. & \multicolumn{1}{|c|}{ Jenis Kelamin } & Frekuensi (orang) & Persentase (\%) \\
\hline \hline 1 & Laki-laki & 84 & 84,00 \\
\hline 2 & Perempuan & 16 & 16,00 \\
\hline & Jumlah & 100 & 100,00 \\
\hline
\end{tabular}

Sumber : Data primer diolah 


\section{Musran Munizu}

Berdasarkan tabel di atas dapat diketahui bahwa dari 100 orang responden dalam penelitian ini terdapat 84 orang (84\%) laki-laki, dan 16 orang (16\%) perempuan. Jumlah responden laki-laki lebih banyak dibanding dengan jumlah perempuan. Kondisi ini mengindikasikan bahwa secara umum responden yang ditemui dalam pengumpulan data adalah laki-laki (kepala keluarga).

Seperti yang diuraikan pada bagian sebelumnya bahwa analisis yang digunakan untuk menguji hipotesis penelitian ini adalah Analisis Regresi Berganda. Secara operasional telah diuraikan juga bahwa dalam penelitian ini variabel keputusan konsumen merupakan variabel tidak bebas (Y), sedangkan variabel bebasnya adalah strategi bauran pemasaran yang terdiri atas produk (x1), harga (x2), promosi (x3), dan saluran distribusi (x4). Adapun hasil perhitungan analisis regresi linier berganda dengan menggunakan bantuan program SPSS for Windows disajikan pada tabel berikut.

Tabel 2. Ringkasan Hasil Analisis Regresi Linier Berganda

\begin{tabular}{|c|c|c|c|c|}
\hline No. & Variabel & $\begin{array}{c}\text { Koefisien Regresi } \\
(\beta)\end{array}$ & Nilai Fhitung & Sig. \\
\hline 1. & Constanta $=-2,100$ & $\overline{-1}$ & \multirow{5}{*}{24,223} & \multirow{5}{*}{0,000} \\
\hline 2. & $\operatorname{Produk}\left(X_{1}\right)$ & 0,511 & & \\
\hline 3. & Harga $\left(X_{2}\right)$ & 0,322 & & \\
\hline 4. & Tempat $\left(X_{3}\right)$ & 0,426 & & \\
\hline 5. & Promosi $\left(\mathrm{X}_{4}\right)$ & 0,304 & & \\
\hline & \multicolumn{4}{|c|}{$\begin{array}{ll}R=0,894 & F_{\text {tabel }}=3,100 \\
R^{2}=0,799 & a=0,05 \\
n=100 & \end{array}$} \\
\hline
\end{tabular}

Sumber : Data primer diolah

Berdasarkan hasil pada tabel di atas, maka dapat dibuat model persamaan regresi liner berganda dalam penelitian ini sebagai berikut :

\section{$Y=-2,100+0,511 X_{1}+0,322 X_{2}+0,426 X_{3}+0,304 X_{4}$}

Persamaan di atas menunjukkan bahwa : (1) Nilai konstanta $=-2,100$ berarti bahwa tanpa adanya pengaruh variabel produk $\left(X_{1}\right)$, harga $\left(X_{2}\right)$, tempat $\left(X_{3}\right)$, dan promosi $\left(X_{4}\right)$, maka skor keputusan konsumen adalah negatif, (2) Setiap tambahan nilai variabel produk, harga, tempat, dan promosi sebesar 1 satuan akan meningkatkan nilai skor keputusan konsumen secara berurutan sebesar 0,$511 ; 0,322 ; 0,426$; dan 0,304 satuan dengan asumsi variabel lain tetap.

Besarnya hubungan antar variabel dapat diketahui dengan melihat angka koefisien korelasi (r). Dari tabel tabel diatas dapat diketahui bahwa nilai $r=0,894$. Hasil ini berarti bahwa hubungan antara variabel produk, harga, promosi, dan distibusi dengan keputusan konsumen dalam memilih produk semen bosowa adalah positif dan sangat kuat. Jadi, setiap peningkatan skor variabel produk, harga, saluran distibusi, dan promosi akan diikuti dengan peningkatan skor keputusan konsumen.

Kemudian nilai $\mathrm{R}^{2}$ (koefisien determinasi) menunjukkan tingkat kesesuaian (fit) sebuah model. Hasil perhitungan yang disajikan pada tabel diatas menunjukkan nilai $R^{2}=0,799$. Hal ini berarti bahwa sebesar 79,9\% variasi naik turunnya skor keputusan konsumen dalam memilih produk semen bosowa dipengaruhi oleh variabel produk, harga, saluran distibusi, dan promosi. Sedangkan sisanya sebesar $20,1 \%$ dipengaruhi oleh variabel lain yang tidak diteliti. 
Pengujian secara simultan (Uji-F) digunakan untuk menguji signikansi pengaruh antara variabel bebas terhadap variabel terikat. Teknik pengujiannya dilakukan dengan cara membandingkan nilai $F$ hitung dengan nilai $F_{\text {tabel }}$ pada taraf signifikansi 0,05 dan taraf kepercayaan (level of confidence) sebesar 95\%. Berdasarkan hasil perhitungan analisis regresi linear berganda yang disajikan pada tabel diatas, dapat diketahui bahwa nilai Fhitung lebih besar dari nilai $F_{\text {tabel }}(44,669$ $>3,100$ ), dan nilai signifikansi hitung (sig) $=0,000$ yang lebih kecil dari nilai $a=0,05$. Hasil ini membuktikan bahwa secara simultan atau bersama-sama variabel produk, harga, saluran distibusi, dan promosi mempunyai pengaruh yang signifikan terhadap keputusan konsumen dalam memilih produk semen bosowa di Kota Makassar.

Selanjutnya pengujian secara parsial (Uji-t) digunakan untuk menguji pengaruh variabel bebas terhadap variabel terikat secara parsial atau secara individual, dan dapat pula digunakan untuk melihat pengaruh variabel bebas yang paling dominan. Secara teknis pengujiannya dilakukan dengan membandingkan nilai thitung dengan nilai ttabel pada taraf signifikansi $a=0,05$. Berdasarkan hasil perhitungan pada lampiran, maka hasil pengujian secara parsial (uji-t) dapat disajikan pada tabel berikut.

Tabel 3. Hasil Pengujian Secara Parsial (Uji-t)

\begin{tabular}{|c|l|c|c|c|}
\hline No. & \multicolumn{1}{|c|}{ Variabel } & Nilai thitung & Sig. & Kesimpulan \\
\hline \hline 1. & Produk $\left(\mathrm{X}_{1}\right)$ & 6,517 & 0,000 & Signifikan \\
\hline 2. & Harga $\left(\mathrm{X}_{2}\right)$ & 5,201 & 0,000 & Signifikan \\
\hline 3. & Tempat/Distribusi $\left(\mathrm{X}_{3}\right)$ & 5,828 & 0,000 & Signifikan \\
\hline 4. & Promosi $\left(\mathrm{X}_{4}\right)$ & 4,010 & 0,001 & Signifikan \\
\hline & $\begin{array}{l}t_{\text {tabel }}=1,980 \quad \text { a }=0,05 \\
\mathrm{n}=100\end{array}$
\end{tabular}

Sumber : Data primer diolah

Hasil pengujian secara parsial (uji-t) yang dirangkum pada tabel diatas menunjukkan bahwa variabel yang mempunyai pengaruh yang paling dominan terhadap terhadap keputusan konsumen produk semen bosowa adalah variabel yang memiliki nilai thitung yang lebih besar dibanding variabel lain dalam penelitian ini. Berdasarkan hal tersebut, maka variabel/faktor produk (x1) mempunyai nilai thitung yang lebih jika dibandingkan dengan variabel lain, yaitu sebesar 6,517. Sehingga dapat disimpulkan bahwa variabel produk mempunyai pengaruh yang paling dominan terhadap keputusan konsumen dalam menggunakan produk semen bosowa di Kota Makassar.

Hasil penelitian ini sejalan dengan penelitian sebelumnya yang menemukan bahwa produk, harga, promosi dan tempat berpengaruh terhadap pengambilan keputusan konsumen (Suryadi dan Hutomo, 2005; Sutrisno, 2007; dan Parengkuan dan Sepang, 2010). Secara konseptual Kotler (2000) menegaskan bahwa aspek produksi, promosi, tempat, karyawan, sarana fisik dan proses pelayanan mempunyai pengaruh yang kuat terhadap keputusan nasabah dalam memilih produk. Secara empirik menunjukkan bahwa produk yang berkualitas, disain produk yang baik dan bervariasi dapat mendorong konsumen untuk melakukan pembelian, sehingga tingkat penjualan perusahaan meningkat.

Tjiptono (2003) mengatakan bahwa variasi produk dan kualitas produk yang baik menjadikan pelanggan mempunyai banyak pilihan terhadap produk yang ditawarkan oleh perusahaan. Semakin tepat kebijakan penetapan harga produk perusahaan, yaitu harga yang bersaing serta diikuti dengan kualitas produk yang baik dapat mempengaruhi keputusan konsumen terhadap produk tersebut. Hal ini secara langsung juga akan mendorong peningkatan penjualan perusahaan. 


\section{Musran Munizu}

Penyesuaian harga produk juga harus dilakukan secara tepat karena pelanggan secara umum sangat sensitif terhadap perubahan harga. kebijakan promosi produk perusahaan, maka akan semakin tinggi tingkat penjualan perusahaan. Pilihan media promosi yang tepat, pesan-pesan yang komunikatif dan mudah dipahami oleh pelanggan dapat mempengaruhi keputusan pelanggan dalam membeli produk (Kotler dan Keller, 2007). Apabila pelanggan mempunyai banyak informasi tentang produk-produk tersebut. saluran distribusi yang didukung dengan lancarnya pengiriman (delivery system) produk perusahaan kepada pelanggan, maka akan semakin tinggi tingkat penjualan perusahaan (Cravens, 2001; Hawkins et al., 2006). Faktanya bahwa secara umum pelanggan akan memutuskan pembelian produk pada perusahaan yang memiliki distribusi dan jaringan pemasaran yang luas dan handal. Hal ini disebabkan karena pelanggan merasa senang dan puas terhadap pelayanan dalam hal pengiriman produk yang tepat waktu.

\section{KESIMPULAN DAN SARAN}

\section{Kesimpulan}

Berdasarkan hasil penelitian dan pembahasan yang telah diuraikan pada bagian sebelumnya, maka dapat ditarik beberapa kesimpulan sebagai berikut :

1. Hasil analisis menunjukkan bahwa baik secara simultan, maupun secara parsial variabel strategi bauran pemasaran yang terdiri atas produk, harga, saluran distibusi, dan promosi berpengaruh positif dan signifikan terhadap keputusan konsumen.

2. Faktor produk merupakan variabel yang paling dominan berpengaruh terhadap terhadap keputusan konsumen dalam menggunakan produk semen bosowa di Kota Makassar. Pengaruh faktor produk yang dominan dalam mempengaruhi keputusan konsumen ditentukan oleh kualitas produk, variasi produk, dan kesesuaian antara kualitas dan harga yang dibayar oleh konsumen.

3. Besarnya kontribusi pengaruh variabel produk, harga, saluran distibusi, dan promosi terhadap keputusan konsumen dalam menggunakan produk semen bosowa adalah sebesar $79,9 \%$. Sedangkan sisanya sebesar $20,1 \%$ dipengaruhi oleh faktor lain diluar model atau faktor lain yang tidak diteliti.

Saran

1. Pihak manajemen perusahaan perlu secara kontinyu dan konsiten untuk lebih memfokuskan perhatiannya pada penetapan dan evaluasi strategi bauran pemasaran pada faktor produk, harga, promosi, dan saluran distribusi pemasaran perusahaan. Karena keputusan konsumen dalam melakukan pembelian produk perusahaan ditentukan oleh keempat faktor tersebut.

2. Kebijakan dalam hal peningkatan kualitas produk baik disain, spesifikasi maupun variasinya tetap dipertahankan bahkan dapat ditingkatkan secara terus menerus. Disamping itu perusahaan juga harus tetap memperhatikan faktor lain seperti, kebijakan penetapan harga yang bersaing, pemilihan media promosi yang tepat, dan kecepatan pengiriman (speed of delivery) produk kepada konsumen.

\section{DAFTAR PUSTAKA}

Basuswastha. 2002. Manajemen Pemasaran Modern, Cetakan Kesembilan, Liberty, Yogyakarta. Boyd dan Walker, 2005. Manajemen Pemasaran, Suatu Pendekatan Strategis dengan Orientasi Global, Erlangga, Jakarta.

Cooper, Donald R. Dan C.William Emory. 1999. Business Research Methods, Fifth Edition, Chicago : Richard D. Irwin Inc. 


\section{Jurnal Manajemen Teori dan Terapan Tahun 5. No. 2. Agustus 2012}

Cravens, W. David. 2001. Pemasaran Strategis, Edisi Kelima, Jilid I dan II, Erlangga, Jakarta.

Hawkins, Del I, Best, R.J, Coney. K.A. 2006. Consumer Behavior: Building Marketing Strategy, International Edition, McGraw-Hill Companies, Inc. New York, USA.

Hitt, Michael, Ireland and Hoskisson. 2004. Manajemen Strategis: Menyongsong Era Persaingan dan Globalisasi, Edisi Terjemahan, Penerbit Erlangga, Jakarta.

Keegan, J. Warren. 2001. Manajemen Pemasaran Global, Jilid I dan II, Prenhallindo, Jakarta.

Kotler, Philips. 2000. Marketing Management, The Millenium Edition. New Jersey : Prentice- Hall Inc.

Kotler, Philips. dan Keller, K.L. 2007. Manajemen Pemasaran. Jilid 1 dan 2 (Terjemahan). Penerbit Indeks, Jakarta.

Parengkuan, Tommy and Sepang, Jantje L. 2010. Pengaruh Strategi Bauran Pemasaran Terhadap Keputusan Konsumen Pada Rental Mobil CV. Central Manado. Jurnal Inovasi Manajemen, 6 (2). pp. 162-172.

Peter, J., Paul and Jerry C. Olson. 2000. Perilaku Konsumen dan Strategi Pemasaran, Jilid I dan II, Erlangga, Jakarta.

Purwadi, Budi. 2005, Riset Pemasaran: Implementasi dan Bauran Pemasaran, PT. Grasindo, Jakarta.

Sugiyono. 2008. Statistika Untuk Penelitian, Revisi Terbaru, CV. Alfabeta, Bandung.

Solimun. 2006. Modul Metode Kuantitatif untuk Manajemen, Materi Program Doktor Manajemen. Pascasarjana Universitas Brawijaya Malang.

Supranto, J. 2005. Pengukuran Tingkat Kepuasan Konsumen, Rineka Cipta, Jakarta.

Suryadi, Edy, dan Doni Hutomo. 2005. Pengaruh Bauran Pemasaran terhadap Keputusan Konsumen dalam Pembelian Kartu Prabayar IM3 di Kota Pontianak, Digilibrary Universitas Muhamadiyah, Pontianak.

Sutrisno, Erryfan. 2007. Pengaruh Bauran Pemasaran (marketing mix) terhadap Pengambilan Keputusan Konsumen dalam Pemilihan Kredit pada Koperasi Serba Usaha Makmur Sejati, Malang. Tesis UMM malang (tidak dipublikasikan).

Tjiptono, Fandy. 2003. Perspektif Manajemen Pemasaran Kontemporer, Penerbit Andi, Yogyakarta. 